\title{
Local awareness and perceptions: consequences for conservation of marsh habitat at Lake Alaotra for one of the world's rarest lemurs
}

\author{
Patrick O. Waeber, Lena M. Reibelt, Ihoby H. Randriamalala \\ Gabrielle Moser, Lucile M. Raveloarimalala, Fidy B. Ralainasolo \\ JONAH RATSIMBAZAFY and LANCE WOOLAVER
}

\begin{abstract}
Management and monitoring of communitybased protected areas in Madagascar remain challenging because of a lack of financial, human and technical resources, and capacity. At Lake Alaotra, conversion of marshland for rice cultivation and a lack of effective habitat protection have pushed the locally endemic Alaotra gentle lemur Hapalemur alaotrensis to the brink of extinction. The highest density of the species is found in the locally managed Park Bandro, a high-priority conservation zone within the Lake Alaotra New Protected Area. We evaluated local awareness and perceptions of Park Bandro, and discussed preferred management options with local communities. Two questionnaire surveys were carried out, one with 180 participants at six sites around the lake and marsh, and another with 50 participants in the village adjacent to Park Bandro. The majority of participants knew of the existence of Park Bandro but most did not know its purpose or size. Values and perceptions of local communities were influenced by occupation and distance to the Park, with fishers being most aware of the Park. We found that local people had a high level of environmental awareness and were willing to discuss zonation and alternative resource management strategies as long as these activities could provide a tangible livelihood benefit. Lack of awareness among local resource users regarding the purpose and status of protected areas such as Park Bandro is a challenge that needs to be addressed, and one that is relevant for environmental
\end{abstract}

Patrick O. Waeber* (Corresponding author), Lena M. Reibelt†, Ihoby H. Randriamalala, Lucile M. Raveloarimalala, Fidy B. Ralainasolo $\neq$, Jonah RATSIMBAZAFY $\$ Madagascar Wildlife Conservation, Lot 17420 bis Avaradrova Sud, 503 Ambatondrazaka, Madagascar. E-mail patrick.waeber@usys.ethz.ch

Gabrielle Moser ETH Zurich, Ecosystems Management, Forest Management and Development Group, Zurich, Switzerland

LANCE Woolaver Durrell Wildlife Conservation Trust, Antananarivo, Madagascar

*Also at: ETH Zurich, Ecosystems Management, Forest Management and Development Group, Zurich, Switzerland

$\dagger$ Also at: University of Hildesheim, Ecology and Environmental Education Group, Institute of Biology and Chemistry, Hildesheim, Germany ¥Also at: Durrell Wildlife Conservation Trust, Antananarivo, Madagascar $\$$ Also at: Groupe d'Etude et de Recherche sur les Primates de Madagascar, Antananarivo, Madagascar

Received 18 May 2016. Revision requested 3 August 2016.

Accepted 27 September 2016. First published online 20 January 2017. education and management of protected areas throughout Madagascar.

Keywords Alaotra gentle lemur, biodiversity conservation, Hapalemur alaotrensis, Madagascar, protected area, stakeholders, values, wetlands

The supplementary material for this article can be found at https://doi.org/10.1017/So030605316001198

\section{Introduction}

central pillar of the conservation of threatened species 1 and biodiversity is the establishment of protected areas, with $15.4 \%$ of terrestrial surfaces having some form of protected status (Deguignet et al., 2014). Of the six IUCN categories of protected areas (cf. Dudley et al., 2010) only Category V (protected landscape/seascape) focuses on human-nature interactions (Gardner, 2011). During the 6th World Parks Congress in 2014 it was recognized that protected areas are not to be appreciated solely for intrinsic values but are to be seen as a reservoir for future generations to safeguard ecosystem services for the surrounding local communities (McNeely, 2015). This is in line with the paradigm change that has occurred since the mid 2oth century, in which conservation has moved away from 'nature for itself towards 'people and nature' (Mace, 2014).

Madagascar was one of the first countries to establish a protected area network, creating its first National Park in 1927. At the 5th World Parks Congress in 2003 Madagascar declared it would triple the terrestrial surface under national protection, to 6 million ha, under the Durban Vision (Norris, 2006). The new System of Protected Areas of Madagascar, which includes the management of the original protected areas as well as New Protected Areas, is responsible for safeguarding biodiversity and cultural heritage and sustainably managing resources for the people of Madagascar (Commission SAPM, 2006). Although the integration of mutual benefits for human well-being and biodiversity has increasingly become the focus in Madagascar (Reibelt \& Nowack, 2015), the management and monitoring of protected areas is proving to be difficult because of a lack of 
technical capacity and financial and human resources (Rakotoarivelo et al., 2011; Rasolofoson et al., 2015; Waeber et al., 2016).

The Critically Endangered Alaotra gentle lemur Hapalemur alaotrensis (Andriaholinirina et al., 2014) is the only lemur species that lives exclusively in marsh habitat (Waeber et al., 2017), and the entire global population of the species is found in the marshes surrounding Lake Alaotra, within the boundaries of the Lake Alaotra New Protected Area. The species faces a high extinction risk as a result of a significant decline in population size and an ongoing reduction in the area, extent and quality of marsh habitat. The population declined from 7,500-11,000 individuals in 1994 (Mutschler \& Feistner, 1995) to $<2,500$ by 2005 (Ralainasolo et al., 2006), and has continued to decline. Historically, $H$. alaotrensis has been poached for keeping as pets and for food (Mutschler et al., 2001; Andrianandrasana et al., 2005). Although hunting pressure has declined in recent years, destruction of the lemur's marsh habitat continues unabated (Ratsimbazafy et al., 2013) and presents a threat to the survival of the species.

Park Bandro is situated in the marshes managed by the village of Andreba and is designated a priority conservation zone, representing the highest conservation category within the New Protected Area. The 85 ha Park shelters the highest density of H. alaotrensis (Ratsimbazafy et al., 2013) and is the best place for seeing the species in the wild (Rendigs et al., 2015). Experiences elsewhere have shown the importance of local people's acceptance and attitudes towards zones set aside for conservation (Ormsby \& Kaplin, 2005; Bennett \& Dearden, 2014; Osunsina \& Fagbeyiro, 2015). The objectives of our study were to evaluate local awareness and perceptions of Park Bandro, assess preferred management options within the local communities surrounding the Lake Alaotra New Protected Areas, and to provide guidance for future environmental education and management plans.

\section{Study area}

The Alaotra region is characterized by an agriculturally dominated landscape that is also home to small-range endemic taxa, including $H$. alaotrensis. Lake Alaotra covers 20,000 ha and is the largest lake in Madagascar; it is surrounded by 25,000 ha of marshland and 130,000 ha of rice fields (Fig. 1). The area is of high socio-economic importance as Madagascar's largest area for production of rice and fish (Copsey et al., 2009a,b). The Alaotra wetlands were designated a wetland of international importance under the Ramsar Convention in 2003, and in 2007 the area was given temporary New Protected Area status in national law. Permanent protected area status was approved in June 2015 and the area was designated a communitymanaged protected area (IUCN Category V).

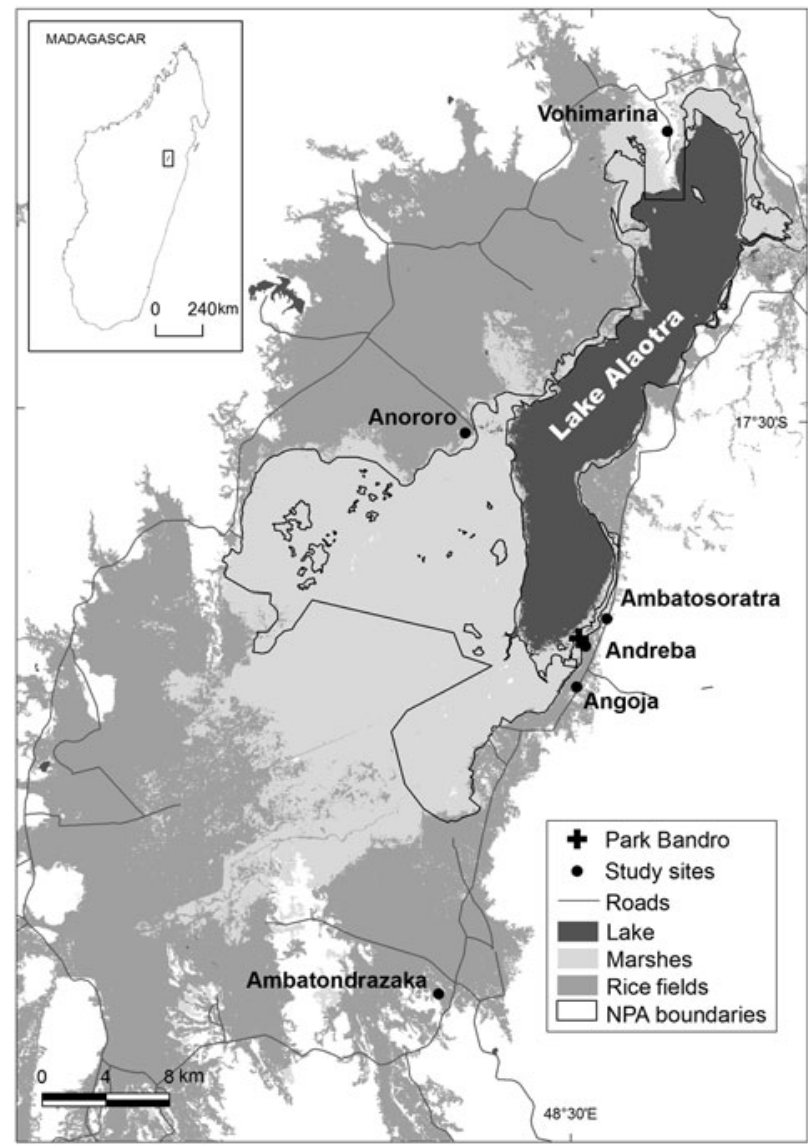

FIG. 1 The locations of the six study sites in the vicinity of the Lake Alaotra New Protected Area (NPA), in Madagascar.

The human population around Lake Alaotra is dependent on fishing and rice cultivation (Ranarijaona, 2007; Wallace et al., 2015). Marsh burning, siltation and conversion to rice fields have reduced the marshes of Lake Alaotra to $<25 \%$ of their historical extent of 60 ,ooo80,000 ha (Bakoariniaina et al., 2006). Conversion of marshland for rice cultivation has escalated, coordinated by people of power from outside the region, for their own financial benefit and aided by a low level of law enforcement (Ratsimbazafy et al., 2013; Waeber \& Wilmé, 2013). This pressure and the lack of legal protection for the marsh prior to the permanent status granted for the Lake Alaotra New Protected Area in June 2015 have brought H. alaotrensis to the brink of extinction.

\section{Methods}

Two surveys were conducted in 2015 to quantify the levels of knowledge and awareness of Park Bandro amongst communities around Lake Alaotra. Survey 1 was carried out in July 2015, with 180 participants in six villages around the lake: Ambatondrazaka, Anororo, Vohimarina, Ambatosoratra, Andreba and Angoja (Fig. 1), selected to represent varying 
TABLE 1 Details of participants in questionnaire surveys carried out around Lake Alaotra, Madagascar (Fig. 1), in 2015, with study village, region, distance to Park Bandro, sample size, age range of participants, and main livelihood activities.

\begin{tabular}{llllll}
\hline Village & Region & $\begin{array}{l}\text { Distance to Park } \\
\text { Bandro }(\mathrm{km})\end{array}$ & $\begin{array}{l}\text { Sample size } \\
\text { (male/female) }\end{array}$ & $\begin{array}{l}\text { Age range } \\
\text { (years) }\end{array}$ & Main livelihood activities \\
\hline $\begin{array}{l}\text { Survey 1 } \\
\text { Ambatondrazaka }\end{array}$ & South & 24.0 & $30(16 / 14)$ & $14-60$ & Student, farmer, houseworker \\
$\begin{array}{l}\text { Anororo } \\
\text { Vohimarina }\end{array}$ & West & 14.7 & $30(24 / 6)$ & $16-67$ & Fisher, weaver, farmer \\
$\begin{array}{l}\text { Ambatosoratra } \\
\text { Andreba }\end{array}$ & North & 32.4 & $30(17 / 13)$ & $15-75$ & $\begin{array}{l}\text { Farmer, fisher, weaver } \\
\text { Angoja }\end{array}$ \\
$\begin{array}{l}\text { Survey 2 } \\
\text { Andreba }\end{array}$ & East & 2.1 & $30(26 / 4)$ & $18-60$ & Fisher, farmer, duck herder \\
\hline
\end{tabular}

distance from Park Bandro. Survey 2, in September 2015, targeted 50 participants, all from Andreba, which is the village closest to Park Bandro. Both surveys collected information on the age, gender, level of education, geographical location and main livelihood activity of each interviewee (Table 1).

We applied purposive sampling (Bernard, 2006) at each site, interviewing participants at the lake or close to the marshes, and at the closest market where the products from the lake and marshes are sold. We assumed that people interviewed along the marshland borders and at the market were natural resource users and were in some way, directly or indirectly, affecting or dependent on the marsh and lake system. For Survey 1 we questioned 10 participants in the morning, 10 at noon and 10 in the evening (i.e. 30 interviewees per site). Surveys were anonymous and administered in Malagasy by two research assistants, who were briefed and trained beforehand. One of the research assistants led the survey and the other took notes to compensate for varying levels of literacy among interviewees. Notes were translated into French and the resulting raw data delivered to and discussed with the researchers. Survey questions had been formulated in French, translated into Malagasy, and then translated back to French to refine the wording and meaning; pilot studies had been conducted for both surveys, and questions were adjusted where needed to eliminate ambiguity. Except for ranking questions and questions about management options (Supplementary Material) and differences inside and outside Park Bandro, the questionnaire contained open questions. For responses to the open questions we conducted quantitative content analysis with inductive creation and establishment of categories (cf. Lamnek, 2005). The categories were discussed and adapted in an iterative process within the research team. Categories were then translated into English before statistical analysis. Summary statistics of all answers were calculated (i.e. percentages, mean and median). To test for differences we used Fisher's exact test, the $\chi^{2}$ test, the $t$-test and the two-sample Wilcoxon rank-sum test in $R$ v. 3.o.3 and v. 3.2.1 (R Development Core Team, 2015). We followed the principles described in the ethical code of conduct of Wilmé et al. (2016).
Survey 1 focused on quantifying people's knowledge about Park Bandro. Questions focused on whether participants knew of the existence of the Park, and its size and purpose, whether they visited it and why, whether they perceived individual benefits or constraints resulting from the Park's existence, and what kind of management option they would prefer. Survey 2 focused on the village of Andreba and explored the values of various land and resource uses. The survey addressed people's perceptions of the conservation importance of Park Bandro, the role and benefits of locally engaged NGOs, the impact of the establishment of the Park, and management options for the marshes and fishery.

\section{Results}

In Survey $158 \%$ of the 180 participants indicated fishing was their main livelihood activity, followed by farming (17\%), student $(6 \%)$, and weaving (3\%); the remaining $16 \%$ replied 'other' (e.g. fish collector, duck herder, teacher). A higher proportion of respondents in Survey 2 were farmers $(40 \%$ of the 50 participants), followed by fishers $(28 \%)$, students $(10 \%)$, weavers $(4 \%)$ and other $(18 \%)$.

To examine differences in levels of environmental awareness between sites and user groups we compared years of schooling between smaller, remote villages around the lake (Anororo, Vohimarina, Ambatosoratra, Andreba and Angoja) and the regional capital (Ambatondrazaka), and between user groups. Participants from Ambatondrazaka had significantly more years of schooling (mean 10.1) than participants from any of the lake-adjacent sites (all sites, $t$-test, $\mathrm{P}<0.0001$; overall mean $=6.9$ ). Fishers exhibited the highest levels of environmental awareness despite having significantly fewer years of schooling than all other user groups $(t$-test, $\mathrm{P}=0.0001)$.

\section{Park Bandro}

Over half of the 180 participants (56\%) in Survey 1 were aware of the existence of Park Bandro. People living in 


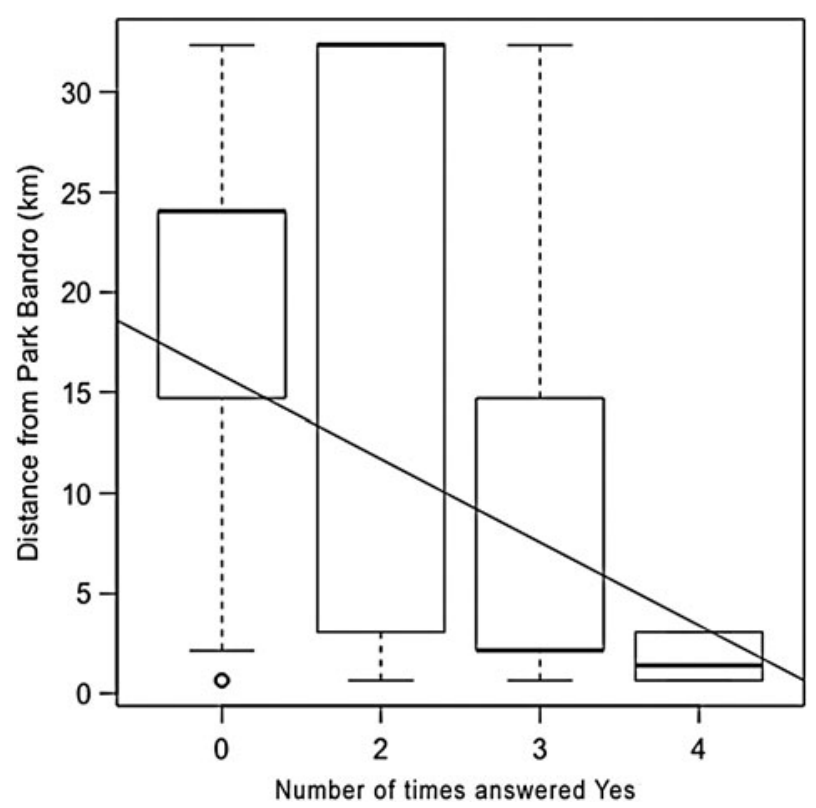

FIg. 2 A boxplot showing correlation between distance to Park Bandro (cf. Fig. 1) and the composite variables (i.e. all questions that could be answered yes or no), with the linear regression line.

villages closer to the Park showed higher levels of awareness than those living further away (Fig. 2; Fisher's exact test, $\mathrm{P}<0.0001$ ). Significantly more fishers knew about the Park than non-fishers (Fisher's exact test, $\mathrm{P}<0.0001$ ). When asked about the Park's legal status $13 \%$ of participants said it was a protected area, another $12 \%$ correctly stated that it was managed by the local community association (Table 2), $11 \%$ believed it was a National Park, and $64 \%$ did not know its legal status. When asked to estimate the size of the Park, $67 \%$ did not know, $22 \%$ estimated $<25$ ha, and $11 \%$ estimated $25-28$ ha. Thirty percent stated that the Park had been created for conservation, and $61 \%$ did not know the purpose of the Park. The remainder thought it had been created for fish production (4\%), tourism ( $2 \%)$, job creation and community benefit $(2 \%)$, and for the environment (1\%). The most frequently cited advantages of Park Bandro were conservation (39\%), tourism (21\%) and job opportunities (16\%). No one cited any disadvantages.

A subsample of 30 people from Andreba were asked in Survey 1 about differences in the status of plants and animals within and outside Park Bandro. The most common replies were that more animals ( $27 \%$ of replies) and denser vegetation (20\%) are found inside the Park. Conversely, respondents stated that there were fewer animals ( $13 \%$ of replies) and less vegetation (17\%) outside the Park, and that exploitation of animals $(27 \%)$ and plants (20\%) occurred outside the Park (Table 2).

All 50 participants in Survey 2 stated that Park Bandro did not inconvenience them, the most common reasons being that there is enough area outside the Park for them to work $(32 \%)$ and that areas where people work do not overlap with the Park (34\%). When asked about changes since the Park's creation in 2004, people replied that numbers of $H$. alaotrensis (mentioned in $52 \%$ of replies), tourists $(50 \%)$ and fish $(50 \%)$ had increased.

\section{Values and perceptions of the marshes}

In Survey 2, focused on the village of Andreba, the 50 participants were asked what the marshes meant to them. The most common answers were habitat for wildlife (23\%), a place to make a livelihood (15\%), a source of handicraft materials $(15 \%)$, fish habitat $(13 \%)$, water reservoir (11\%), and plant diversity (9\%). All participants considered the marsh to be important, the main reasons being that it supports livelihoods (15\%), attracts rainfall $(13 \%)$, and serves as fish habitat $(12 \%)$. When comparing the marshes with other land types, such as open lake, agricultural zone, forest, and open landscape, respondents considered the marshes to be the most important habitat, ranking open landscape as the least important land type (Fig. 3). The main reason given for the highest ranking was that the marsh was a place of work supporting local livelihoods (Table 3 ).

\section{Conservation and management}

To examine the local community's awareness and perception of NGOs the 50 participants in Survey 2 were asked which NGOs were active in their local area (Table 4). The most common replies were the VOI (a general term for a community association; $82 \%$ of replies) and Zetra Maintso (a village association concerned with marsh management; $38 \%$ ); specific conservation NGOs were also mentioned, including Durrell Wildlife Conservation Trust and Madagascar Wildlife Conservation (22\%). Regarding NGO activities, the most common responses were marshland protection (22\%), environmental awareness (11\%) and rural development (9\%). Regarding fishery and marshland management, only $6 \%$ of participants $(n=50)$ opted for no temporal or spatial fishing closure (Management strategy A, Supplementary Material; Table 4). The main reasons given were that fishing is a gift from God, and that fishing should be allowed year round. Forty-six percent of people opted for no temporal closure but with fixed conservation zones, as this would 'allow fishing year round' and 'allow for fish development' (Management strategy B, Supplementary Material). Forty-eight percent of interviewees opted for a closed fishing season (Management strategy C, Supplementary Material), a policy that is currently in place. Most common responses in support of a closed season were the 'promotion of fish reproduction' and 'fish development'.

\section{Discussion}

In situ efforts for lemur conservation have thus far focused on ecological monitoring by the Comite Forestier 
TABLE 2 Responses to a questionnaire survey carried out around Lake Alaotra, Madagascar (Fig. 1), in 2015, to elicit the perceptions of local communities about the Park Bandro protected area.

\begin{tabular}{|c|c|c|}
\hline Questionnaire responses & Sample size & No. of respondents (\%) \\
\hline \multicolumn{3}{|l|}{ Park's legal status } \\
\hline Protected area & 180 & $23(12.8)$ \\
\hline Managed by community association & 180 & $21(11.7)$ \\
\hline National Park & 180 & $18(10)$ \\
\hline National Park, managed by community association & 180 & $2(1.1)$ \\
\hline Don't know & 180 & $116(64.4)$ \\
\hline \multicolumn{3}{|l|}{ Park size (ha) } \\
\hline $1-85$ & 180 & $59(32.8)$ \\
\hline $0-5$ & 180 & $16(8.9)$ \\
\hline $6-25$ & 180 & $23(12.8)$ \\
\hline $26-36$ & 180 & $5(2.8)$ \\
\hline $37-85$ & 180 & $15(8.3)$ \\
\hline Don't know & 180 & $121(67.2)$ \\
\hline \multicolumn{3}{|l|}{ Park location } \\
\hline Near Andreba & 180 & $101(56.1)$ \\
\hline Don’t know & 180 & $79(43.9)$ \\
\hline \multicolumn{3}{|l|}{ Park objective } \\
\hline Conservation & 180 & $54(30)$ \\
\hline Fish production & 180 & $8(4.4)$ \\
\hline Attract tourism & 180 & $3(1.7)$ \\
\hline Environment & 180 & $2(1.1)$ \\
\hline Community benefits & 180 & $1(0.6)$ \\
\hline Job creation & 180 & $1(0.6)$ \\
\hline Conservation \& tourism & 180 & $1(0.6)$ \\
\hline Creation by the government & 180 & $1(0.6)$ \\
\hline Don’t know & 180 & $109(60.6)$ \\
\hline \multicolumn{3}{|l|}{ Park advantages } \\
\hline Conservation & 180 & $70(38.9)$ \\
\hline Tourism & 180 & $38(21.1)$ \\
\hline Other job opportunities & 180 & $29(16.1)$ \\
\hline Pleasure & 180 & $7(3.9)$ \\
\hline Increased precipitation & 180 & $7(3.9)$ \\
\hline Prestige & 180 & $6(3.3)$ \\
\hline \multicolumn{3}{|l|}{ Differences between inside \& outside the Park } \\
\hline More animals inside the Park & 30 & $8(26.7)$ \\
\hline Denser vegetation inside the Park & 30 & $6(20)$ \\
\hline Park is used for conservation & 30 & $8(26.7)$ \\
\hline Fewer animals outside the Park & 30 & $4(13.3)$ \\
\hline Animals are exploited outside the Park & 30 & $8(26.7)$ \\
\hline Plants are exploited outside the Park & 30 & $6(20)$ \\
\hline Fewer plants outside the Park & 30 & $5(16.7)$ \\
\hline \multicolumn{3}{|l|}{ Perceptions of Park Bandro } \\
\hline It is not inconvenient & 50 & $50(100)$ \\
\hline There is enough area outside the Park to work & 50 & $16(32)$ \\
\hline The Park does not overlap with work areas & 50 & $17(34)$ \\
\hline \multicolumn{3}{|l|}{ What has changed since the Park's creation in $2004 ?$} \\
\hline Increase in the number of $H$. alaotrensis & 50 & $26(52)$ \\
\hline Increase in the number of tourists & 50 & $25(50)$ \\
\hline Increase in the number of fish & 50 & $25(50)$ \\
\hline Decrease in marshland degradation & 50 & $10(20)$ \\
\hline Increase in local income & 50 & $9(18)$ \\
\hline
\end{tabular}

Local network (Andrianandrasana et al., 2005), reporting and documenting marshland fires within the protected area (Ratsimbazafy et al., 2013), and establishing community engagement (Rendigs et al., 2015). Anthropogenic pressure is high and increasing (Ratsimbazafy et al., 2013). There was little law enforcement, especially during the years of political crisis (2009-2013), with land conversion for rice production instigated by actors from outside 

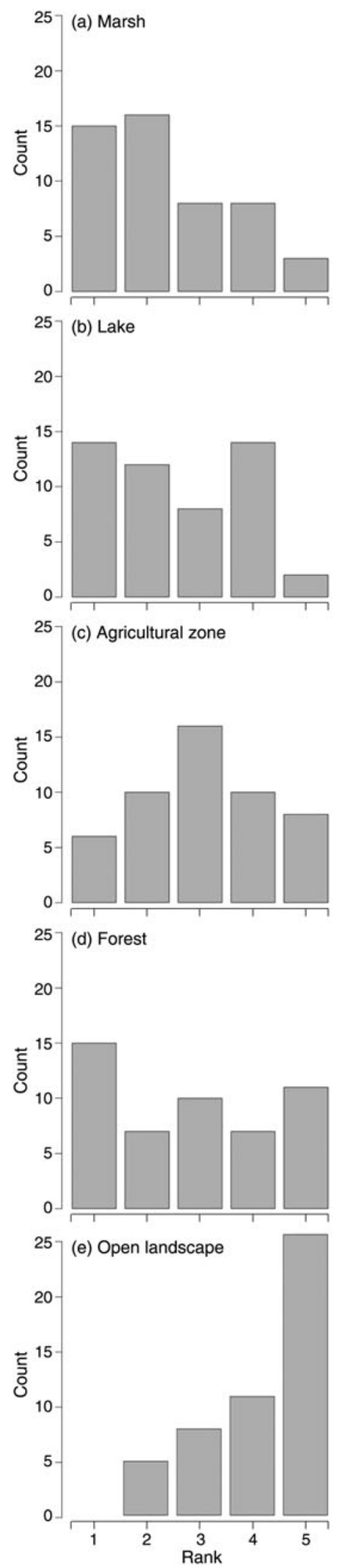

FIG. 3 Ranking of land zones by the 50 participants from Andreba (Fig. 1) according to importance ( $1=$ very important, $5=$ not important at all). (a) Marsh, (b) Lake, (c) Agricultural zone, (d) Forest, (e) Open landscape. the Alaotra system (Waeber \& Wilmé, 2013; Garcia et al., 2015). The challenge for conserving the Alaotra gentle lemur is that increasing numbers of people are entering the marshes of Alaotra to pursue livelihood strategies and converting marsh to rice fields. However, participants stated that they respected the boundaries of Park Bandro and did not perceive any inconvenience from its existence. They also believed the Park was important for increasing fish stocks and local income. However, none of the participants knew the size or exact boundaries of the Park, and the legal status and goal of the Park were unclear to most people. A similar scenario was reported for Masoala National Park, where residents were aware of the Park's existence but not of its purpose (Ormsby \& Kaplin, 2005). In reality the availability of lemur habitat in Park Bandro is declining as a result of encroachment by illegally established rice fields. Enforcement of environmental laws has been hampered at Alaotra by the lack of visible boundary markers for protected areas, even for strict conservation zones such as Park Bandro, which have been decided upon by local communities themselves during open, transparent meetings. Our results reinforce this, with the majority of people interviewed unable to state the size and purpose of the Park. Without understanding the purpose and potential positive impacts of a protected area, or knowing the delimitation of a protected area's boundaries, how can local communities be expected to support the protected area and respect its borders? Nonetheless, this illegal land conversion has taken place in small patches and Park Bandro has not experienced a major fire for more than 20 years, in contrast to outside the Park, where large areas of the marshes $(1-45 \%$ per annum during 2000-2009) have been burned during the dry season (Ratsimbazafy et al., 2013).

Understanding the perceptions and values of local communities is an essential step towards conservation management, as local support for such projects is crucial (Agrawal \& Gibson, 1999). Land types such as the lake and marshes were deemed to be more valuable than others because they were related to direct income or indirect but visible ecosystem services such as provision of water, important for both fish and rice production; for example, many primary school teachers in Alaotra perceive the Asian snakehead Channa maculata, an invasive fish species, as a tangible benefit (Reibelt et al., 2014). One factor that shaped the values and perceptions of local communities was distance to the resource. The nearest forest to Alaotra is $10-20 \mathrm{~km}$ away and interviewees did not consider it to be important because they had no direct access to the forest and consequently no direct benefit from it. Similar perceptions have been reported for resource users in the Manompana forest corridor (Urech et al., 2015).

Delivering conservation messages to large populations of resource users in countries such as Madagascar that lack 
TABLE 3 The most common reasons given by Survey 2 participants for highest or lowest ranking of land zones (Fig. 3).

\begin{tabular}{|c|c|c|c|c|c|}
\hline & Forest & Lake & Open landscape & Agricultural zone & Marshes \\
\hline $\begin{array}{l}\text { Reasons } \\
\text { ranked least } \\
\text { important }\end{array}$ & Forest is too far away & $\begin{array}{l}\text { Lake is too risky } \\
\text { (high uncertainty } \\
\text { regarding size of } \\
\text { fish catch) }\end{array}$ & $\begin{array}{l}\text { Infertile soils; } \\
\text { don't work there; } \\
\text { too dry; no benefit; } \\
\text { seasonal work } \\
\text { only; too far away }\end{array}$ & $\begin{array}{l}\text { Don't work there; not en- } \\
\text { ough space; difficult water- } \\
\text { ing; no work; less } \\
\text { important than fishing; this } \\
\text { zone depends on the four } \\
\text { ecosystems (forest, lake, } \\
\text { open landscape/ grass- } \\
\text { lands, marshes) }\end{array}$ & $\begin{array}{l}\text { Occasional work } \\
\text { only; don't work } \\
\text { there; don't know } \\
\text { how to fish }\end{array}$ \\
\hline
\end{tabular}

Reasons Forest attracts rain, Place of work; place None reported ranked most protects soils, and proimportant
Place of work; place
for life; place for

fishing; marshes

depend on the lake
Place of work; place for life; siltation protection; fish habitat; rice plantation; source of income
Place of work; agriculture is prestige; I'm a farmer; my only property

forest

basic infrastructure such as electricity and roads can be a challenge. Furthermore, conservation practitioners in the Alaotra region have questioned whether a single highpriority park such as Park Bandro is actually of value in terms of reaching conservation targets, or whether a number of interconnected protected areas would provide better protection for the lemurs and their marsh habitat. Our results indicate the importance of distance to a high-priority conservation area such as Park Bandro, and suggest it may be easier to increase local awareness of protected areas if a number of smaller high-priority community-managed protected areas were embedded within the larger New Protected Area.

At Lake Alaotra, fishers have a close relationship to the lake and marshes compared with other user groups interviewed. People are connected to the environment they live and work in. For some, the marshes represent a cultural heritage or unique biodiversity that gives the region prestige. For others the marsh is a working environment necessary for survival. This demonstrates the dichotomy of conservation in Alaotra. People are culturally and socially attached to the marshes but they also need the land to cultivate and the fish to sustain the growing population. Regardless of their reasons for attachment to the environment, we found local people were willing to discuss zonation and resource management strategies. They understand that for fish stocks to be sustainable they require space (zones) and time (closed seasons) for fish to reproduce and recover (Wallace et al., 2016). However, in reality Alaotra is an example of the tragedy of the commons (Dietz et al., 2003): many people are ignoring the closed fishing season (November-January), putting further pressure on the common-pool resource, while professional fishers who respect the regulations see the fish stocks shrinking and are tempted to ignore regulations and exploit the diminishing resource (Copsey et al., 2009a). Unregulated immigration into the region to profit from this resource further aggravates the situation. Similarly, although people showed an understanding of the value of the marshes, lake and biodiversity, we found they perceived the main value of the marshes as being a place for work, echoing the idea of parks being 'a reservoir for the future society' (McNeely, 2015). The challenge is therefore the reconciliation of a positive attitude towards an intact ecosystem with the need to generate income for local people.

If conservation activities provide tangible livelihood benefits there is a chance for conservation to succeed. However, the protection of resources with non-market-based values is difficult. The challenge from a conservation perspective remains to increase the attractiveness of protected species without encouraging their commercialization.

Despite favourable attitudes toward resource conservation, formal protection in the form of Ramsar and New Protected Area designations and local community management of Park Bandro, exploitation of fishing grounds and agricultural expansion, at the cost of lemur habitat, continue. A primary reason for this is the lack of physical delimitation of the boundaries of the protected areas, as well as weak law enforcement.

A network of small high-priority sites managed by local community associations may provide increased protection within the New Protected Area, as long as boundaries are clear and visible, and law enforcement is accountable and transparent. The challenge in such a scenario is in maintaining a minimum degree of connectivity. Promoting permanent protection zones (such as Park Bandro) may be acceptable to local communities if they perceive tangible and direct benefits for livelihoods, and interview participants favoured closed fishing seasons and no-take zones. Improved management and protection of the natural resources of Lake Alaotra may benefit both local resource users and $H$. alaotrensis but before we 'talk biodiversity conservation' we first need to be ready to 'talk rice and fish'.

Community involvement is crucial (Reibelt \& Nowack, 2015) and it is important that conservation in Alaotra engages with all stakeholders, and foremost with the 
TABLE 4 Local community perceptions of the roles of conservation NGOs and preferred management options for protected areas at Lake Alaotra, (Fig. 1). There was no significant difference in the choice of management options between occupational groups (fishers, farmers and others).

\begin{tabular}{|c|c|c|}
\hline & $\begin{array}{l}\text { No. of times this } \\
\text { answer was } \\
\text { given }\end{array}$ & $\begin{array}{l}\text { Percentage } \\
(\%), \mathrm{n}=50\end{array}$ \\
\hline \multicolumn{3}{|l|}{ Type of activities done by NGOs (Give 3 reasons) } \\
\hline Marshland protection & 33 & 66 \\
\hline Environmental awareness & 17 & 34 \\
\hline Rural development & 14 & 28 \\
\hline Material donations & 11 & 22 \\
\hline Monitoring fisheries & 9 & 18 \\
\hline Raising awareness to reduce marsh fires & 4 & 8 \\
\hline H. alaotrensis conservation & 4 & 8 \\
\hline Clearing channels of invasive aquatic plants in Park Bandro & 6 & 12 \\
\hline Training in weaving & 4 & 8 \\
\hline Agricultural techniques & 1 & 2 \\
\hline Handicrafts & 1 & 2 \\
\hline Tourism jobs & 2 & 4 \\
\hline \multicolumn{3}{|l|}{ Have you worked with an NGO? } \\
\hline Yes & 12 & 24 \\
\hline No & 36 & 72 \\
\hline No-don't know any NGOs & 2 & 4 \\
\hline \multicolumn{3}{|l|}{ Best way to manage fishery? } \\
\hline Strategy A: without closed fishing seasons or permanent closed fishing zones & 3 & 6 \\
\hline $\begin{array}{l}\text { Strategy B: without closed fishing seasons but with the establishment of permanent reserves where } \\
\text { fishing is prohibited throughout the year }\end{array}$ & 23 & 46 \\
\hline Strategy C: closed fishing season during Nov.-Jan. (a policy that is currently in place) & 24 & 48 \\
\hline \multicolumn{3}{|l|}{ Common reasons for choosing strategy A (Give 2 reasons) } \\
\hline Fishing is a gift from God & 1 & 2 \\
\hline Fishing should be allowed year round & 2 & 4 \\
\hline \multicolumn{3}{|l|}{ Common reasons for choosing strategy B (Give 2 reasons) } \\
\hline Fishing year round & 23 & 46 \\
\hline Allowing for fish development & 11 & 22 \\
\hline \multicolumn{3}{|l|}{ Common reasons for choosing strategy C (Give 2 reasons) } \\
\hline Promotion of fish reproduction & 24 & 48 \\
\hline Fish development & 22 & 44 \\
\hline \multicolumn{3}{|l|}{ Best way to manage marshlands? } \\
\hline $\begin{array}{l}\text { Strategy A: distinct zoning for H. alaotrensis and agriculture (participants from Andreba) } \\
\text { [land sparing] }\end{array}$ & 49 & 98 \\
\hline Strategy B: no zoning at all [land sharing] & 1 & 2 \\
\hline \multicolumn{3}{|l|}{ Common reasons for choosing strategy A (Give 2 reasons) } \\
\hline Better protection of $H$. alaotrensis & 43 & 86 \\
\hline There's enough space for both agriculture and conservation & 17 & 34 \\
\hline To stop hunting of $H$. alaotrensis & 8 & 16 \\
\hline
\end{tabular}

communities that depend directly on the lake and marshland systems, but this has been challenging in the past (Rendigs et al., 2015). A community is not a homogeneous entity but consists of various stakeholders, each with their own agendas and value systems (Berkes, 2004). Conservation organizations need to work more closely with fishers, who know the marshes best and are also an integral part of a social landscape (Richard \& Ratsirarson, 2013), especially where local knowledge about valuable fishing grounds and nurseries needs to be identified during conservation planning.
Increased stakeholder engagement in parallel with concerted habitat conservation efforts within the protected area should result in a better understanding of the purpose and the rules, including the boundaries, of Park Bandro. This requires that management roles and responsibilities are defined collaboratively, transparently and unambiguously among a complex group of stakeholders. The challenge is in developing a range of communication tools and strategies to discuss and administer protected areas most effectively with local resource users. Local community values and perceptions are invaluable, and our findings suggest there is room for 
conservation and improved resource use management within protected areas such as Park Bandro as long as this is balanced with the needs of the local community for food, water and income. There is hope that with improved protection and management Lake Alaotra's marsh and unique lemur can survive in an anthropogenically shared landscape.

\section{Acknowledgements}

We acknowledge the support received from Kiady Rakotondravoninala (Regional Director of the Ministry of Environment, Ecology, Sea and Forests), Samuel Razafindrabe (Regional Director of the Ministry of Agriculture) and Herilalaina Andrianantenaina (Regional Director of the Ministry of Fisheries). We thank our two research assistants, Vanessa Gisèle Aimée Rakotomalala and Olivier Pascal Randriamanjakahasina, for their work at all six study sites. We thank all participants for their trust and participation in this study, and acknowledge the comments of two anonymous reviewers that helped to improve the article. This research was funded by the Margot Marsh Biodiversity Foundation under the research grant PR15-021, and the Swiss Programme for Research on Global Issues for Development under the research grant IZo1Zo_146852 as part of the AlaReLa Alaotra Resilience Landscape project.

\section{Author contributions}

POW, LMR and IHR conceived and designed the study. IHR, LuMR and FBR administered the questionnaires. GM, POW and LMR analysed the data. POW, LMR, LW, IHR, GM and JR wrote the article.

\section{References}

Agrawal, A. \& Gibson, C.C. (1999) Enchantment and disenchantment: the role of community in natural resource conservation. World Development, 27, 629-649.

Andriaholinirina, N., Baden, A., Blanco, M., Chikhi, L., Cooke, A., Davies, N. et al. (2014) Hapalemur alaotrensis. The IUCN Red List of Threatened Species v. 2015.2. Http://www. iucnredlist.org [accessed 30 July 2015].

Andrianandrasana, H.T., Randriamahefasoa, J., Durbin, J., Lewis, R.E. \& Ratsimbazafy, J.H. (2005) Participatory ecological monitoring of the Alaotra wetlands in Madagascar. Biodiversity and Conservation, 14, 2757-2774.

Bakoariniaina, L.N., Kusky, T. \& Raharimahefa, T. (2006) Disappearing Lake Alaotra: monitoring catastrophic erosion, waterway silting, and land degradation hazards in Madagascar using Landsat imagery. Journal of African Earth Sciences, 44, 241-252.

Bennet t, N.J. \& DeArden, P. (2014) Why local people do not support conservation: community perceptions of marine protected area livelihood impacts, governance and management in Thailand. Marine Policy, 44, 107-116.

Berkes, F. (2004) Rethinking community-based conservation. Conservation Biology, 18, 621-630.
Bernard, H.R. (2006) Research Methods in Anthropology: Qualitative and Quantitative Approaches. 3rd edition. AltaMira Press, Walnut Creek, USA.

Commission SAPM (2006) Système d'Aires Protégées de Madagascar: Orientations générales sur les catégories et les types de gouvernance. Unpublished report. Antananarivo, Madagascar.

Copsey, J.A., Rajaonarison, L.H., Randriamihamina, R. \& RAKOTONiaina, L.J. (2009a) Voices from the marsh: livelihood concerns of fishers and rice cultivators in the Alaotra wetland. Madagascar Conservation \& Development, 4, 25-30.

Copsey, J.A., Jones, J.P.G., Andrianandrasana, H.T., Rajaonarison, L.H. \& FA, J.E. (2009b) Burning to fish: local explanations for wetland burning in Lac Alaotra, Madagascar. Oryx, 43, 403-406.

Deguignet, M., Juffe-Bignoli, D., Harrison, J., MacSharry, B., Burgess, N. \& Kingston, N. (2014) 2014 United Nations List of Protected Areas. UNEP-WCMC, Cambridge, UK.

Dietz, T., Ostrom, E. \& Stern, P.C. (2003) The struggle to govern the commons. Science, 302, 1907-1912.

Dudley, N., Parrish, J.D., Redford, K.H. \& Stolton, S. (2010) The revised IUCN protected area management categories: the debate and ways forward. Oryx, 44, 485-49o.

Garcia, C., Dray, A., Aubert, S., Reibelt, L.M. \& Waeber, P.O. (2015) Scenarios of biodiversity exploring possible futures for management. Akon'ny Ala, 32, 1-14.

GARDNER, C.J. (2011) IUCN management categories fail to represent new, multiple-use protected areas in Madagascar. Oryx, 45, 336-346. Lamnek, S. (2005) Qualitative Sozialforschung. Lehrbuch. Beltz, Weinheim, Germany.

MAce, G.M. (2014) Whose conservation? Science, 345, 1558-156o.

McNeely, J.A. (2015) A political future for protected areas. Oryx, 49, 189-190.

Mutschler, T. \& Feistner, A.T.C. (1995) Conservation status and distribution of the Alaotran gentle lemur Hapalemur griseus alaotrensis. Oryx, 29, 267-274.

Mutschler, T., Randrianarisoa, A.J. \& Feistner, A.T.C. (2001) Population status of the Alaotran gentle lemur Hapalemur griseus alaotrensis. Oryx, 35, 152-157.

Norris, S. (2006) Madagascar defiant. BioScience, 56, 960-965.

Ormsby, A. \& Kaplin, B.A. (2005) A framework for understanding community resident perceptions of Masoala National Park, Madagascar. Environmental Conservation, 32, 156-164.

Osunsina, I.O. \& Fagbeyiro, A.O. (2015) Local community perception and attitude towards the non-utilization of natural resources in old Oyo National Park, Oyo State, Nigeria. Journal of Agriculture and Environment for International Development, 109, 291-306.

Rakotoarivelo, A.R., Razafimanahaka, J.H., Rabesihanaka, S., Jones, J.P.G. \& Jenkins, R.K.B. (2011) Laws and regulations on wildlife in Madagascar: progress and future needs. Madagascar Conservation \& Development, 6, 37-44.

Ralainasolo, F.B., Waeber, P.O., Ratsimbazafy, J., Durbin, J. \& LEWIs, R. (2006) The Alaotra gentle lemur: population estimation and subsequent implications. Madagascar Conservation \& Development, 1, 9-10.

RANARIJAONA, H.L.T. (2007) Concept de modèle écologique pour la zone humide Alaotra. Madagascar Conservation \& Development, 2, 35-42.

Rasolofoson, R.A., Ferraro, P.J., Jenkins, C.N. \& Jones, J.P.G. (2015) Effectiveness of community forest management at reducing deforestation in Madagascar. Biological Conservation, 184, 271-277.

Ratsimbazafy, J.H., Ralainasolo, F.B., Rendigs, A., Mantilla-Contreras, J., Andrianandrasana, H., Mandimbihasina, A.R. et al. (2013) Gone in a puff of smoke? Hapalemur alaotrensis at great risk of extinction. Lemur News, 17, 14-18. 
R Development Core Team (2015) R: A Language and Environment for Statistical Computing. R Foundation for Statistical Computing, Vienna, Austria.

Reibelt, L.M. \& Nowack, J. (2015) Community-based conservation in Madagascar, the 'cure-all' solution? Madagascar Conservation \& Development, 10, 3-5.

Reibelt, L.M., Richter, T., Waeber, P.O., Rakotoarimanana, S.H.N.H. \& Mantilla-Contreras, J. (2014) Environmental education in its infancy at Lake Alaotra, Madagascar. Madagascar Conservation \& Development, 9, 71-82.

Rendigs, A., Reibelt, L.M., Ralainasolo, F.B., Ratsimbazaft, J.H. \& WAEBER, P.O. (2015) Ten years into the marshes-Hapalemur alaotrensis conservation, one step forward and two steps back? Madagascar Conservation \& Development, 10, 13-20.

Richard, A.F. \& Ratsirarson, J. (2013) Partnership in practice: making conservation work at Beza Mahafaly, southwest Madagascar. Madagascar Conservation \& Development, 8, 12-20.

Urech, Z.L., Zaehringer, J.G., Rickenbach, O., Sorg, J.-P. \& Felber, H.R. (2015) Understanding deforestation and forest fragmentation from a livelihood perspective. Madagascar Conservation \& Development, 10, 67-76.

Waeber, P.O., Ratsimbazafy, J.H., Andrianandrasana, H., Ralainasolo, F.B. \& Nievergelt, C.M. (2017) Hapalemur alaotrensis, a conservation case study from the swamps of Alaotra, Madagascar. In Primates in Flooded Habitats: Ecology and Conservation (eds A. Barnett, I. Matsuda \& K. Nowak), In press. Cambridge University Press, Cambridge, UK.

WAEBER, P.O. \& WiLMÉ, L. (2013) Madagascar rich and intransparent. Madagascar Conservation \& Development, 8, 52-54.

Waeber, P.O., Wilmé, L., Mercier, J.R., Camara, C. \& Lowry, II, P. P. (2016) How effective have thirty years of internationally driven conservation and development efforts been in Madagascar? PLoS ONE, 11(8), eo161115.
Wallace, A.P.C., Jones, J.P.G., Milner-Gulland, E.J., Wallace, G. E., Young, R. \& Nicholson, E. (2016) Drivers of the distribution of fisher effort at Lake Alaotra, Madagascar. Human Ecology, 44, 105-117.

Wallace, A.P.C., Milner-Gulland, E.J., Jones, J.P.G., Bunnefeld, N., Young, R. \& Nicholson, E. (2015) Quantifying the short-term costs of conservation interventions for fishers at Lake Alaotra, Madagascar. PLoS ONE, 10(6), e0129440.

Wilmé, L., Waeber, P.O., Moutou, F., Gardner, C.J., Razafindratsima, O., Sparks, J. et al. (2016) A proposal for ethical research conduct in Madagascar. Madagascar Conservation \& Development, 11, 36-39.

\section{Biographical sketches}

PATRICK WAEBER is interested in the drivers of interactions between people, wildlife, ecosystems and social norms. Lena ReibeLt is interested in environmental education, and is studying the capacity of teachers in Madagascar and the interplay of education, conservation and sustainable development. Iнов в RANDRIAMALALA is interested in relationships between biodiversity conservation and sustaining rural livelihoods, and balancing conservation values with the vulnerability of rural poor to drivers of change. GABRIELLE MOSER identifies spatial use patterns to inform research for the management of conservation projects and natural resources. LUCILE RAVELOARIMALALA is studying the interactions between ecosystem services and human needs, to improve livelihoods and ensure ecosystem conservation. FIDY RALAINOSOLO researches limiting factors responsible for declining lemur populations. JoNAH RATSIMBAZAFY is passionate about creating global research and advocacy networks to save lemurs from extinction. Lance WOOLAVER manages species recovery projects in Madagascar, integrating captive breeding and reintroduction with wild population management. 